\section{Parameters Associated with Marginal Bone Loss around Implant after Prosthetic Loading}

Clarissa D. Koller, Tatiana Pereira-Cenci, Noéli Boscato
Graduate Program in Dentistry, Dental School, UFPel - Universidade Federal de Pelotas, Pelotas, RS, Brazil

Correspondence: Prof. Noéli Boscato, Rua Gonçalves Chaves 457, s/ 508, 96015-560 Pelotas, RS, Brasil.

Tel: +55-53-3225-6741 ext. 135 . e-mail:noeliboscato@gmail.com

\begin{abstract}
This study evaluated retrospectively the association among occlusal, periodontal and implant-prosthetic parameters and marginal bone loss (MBL) around implants and survival rate at $5.7 \pm 3.2$ years of follow-up after prosthetic loading. Eighty-two patients received 164 external hexagon implants. After the standard healing period (3 to 6 months), the implants were restored with single-tooth or up to three splinted crowns. All patients were followed according to a strict maintenance program with regular recalls and clinically evaluated by a calibrated examiner. The MBL measurements taken from standardized radiographs made at permanent crown placement (baseline) and after the last evaluation were calculated considering occlusal, periodontal and implant-prosthetic parameters. Veneer fractures and abutment loosening were not considered failure. Two implants failed during the follow-up period, resulting in a survival rate of $98.8 \%$. Cox regression analyses showed MBL associated with non-working side contacts $(p=0.047)$, inadequate anterior guidance $(p=0.001)$, lateral group guidance involving teeth and implants $(p=0.015)$, periimplant plaque index $(p=0.035)$, prosthetic design $(p=0.030)$ and retention $(p=0.006)$. Inadequate occlusal pattern guide, presence of visible plaque, and cemented and splinted implant-supported restoration were associated with greater MBL around the implant.
\end{abstract}

Key Words: implant survival, dental implant, observational studies, bone remodeling, occlusal guidance.

\section{Introduction}

Despite the excellent survival rates of dental implants, long-term studies have shown 1.5 to $2 \mathrm{~mm}$ of bone loss around the implant neck during the first year after functional loading $(1,2)$ and an annual rate of marginal bone loss (MBL) around $0.2 \mathrm{~mm}$, after the first year (3). Among other factors, this acceptable bone loss is most likely due to occlusal forces directed on the bone, which responds mechanically to this situation, remodeling it naturally (4). However, when the MBL reaches greater levels than those commonly observed in the first and subsequent years, it is possible that mechanical or biological risk factors had caused this loss, which may culminate in gradual or total loss of osseointegration (5).

A multifactorial background is linked to the onset and progression of marginal bone loss and later complications due to periodontal and implant-prosthetic risk factors such as implant location, prosthetic design and retention $(3,4)$. Excessive surgical trauma together with an impaired healing ability, bacterial infection and biomechanical overload are among the most common causes of early implant losses (5). Progressive chronic peri-implant infection and overload together with the host characteristics are considered as major etiological factors causing late failures (5). It seems that infection alone cannot cause progressive bone resorption, but overloading associated with marginal peri-implant infection could certainly result in MBL and implant failure $(6,7)$. The occlusion of implant-supported prostheses has been assessed but poorly studied in longitudinal clinical studies. Thus, this issue represents a gap in the knowledge of the longevity of the implant-prosthesis assembly $(8,9)$. Although several aspects concerning implant survival rate and peri-implant bone loss have been reported, (1-11) there is still lack of clinical investigations in humans considering the role of unsuitable occlusal factors on the establishment and maintenance of oral implant osseointegration (12-14), together with implant-prosthetic and periodontal parameters.

This study evaluated retrospectively the association among occlusal, periodontal and implant-prosthetic parameters and MBL around implants and survival rates at $5.7 \pm 3.2$ years of follow-up after prosthetic loading. The tested hypothesis was that the MBL is influenced by the evaluated parameters.

\section{Material and Methods Patient Selection}

This cross-sectional observational study was approved by the Local Research Ethics Committee (protocol $n^{\circ}$ 01/2013) and followed the STROBE guidelines for reporting observational trials (15). Included patients were treated by properly trained clinicians at the Graduate Program in Dentistry from August 2004 to December 2013, received external hexagon implants (Neodent, Curitiba, PR, Brazil) following a single protocol (16) and a 3-6 month period was allowed before prosthetic loading. The inclusion criteria for 
enrollment in this study were: a) adequately registered data regarding implant placement and prosthetic rehabilitation; b) metal-ceramic implant prosthetic rehabilitation involving single or up to three splinted crowns; c) baseline periapical radiography with preserved quality; d) continuous clinical follow-up, which included at least one annual recall; e) absence of periodontal disease and f) no need of bone augmentation prior to implant placement. All patients had to be systemically healthy. Exclusion criteria comprised smoking of more than 10 cigarettes per day. The need for a preceding lateral bone augmentation, prior therapeutic radiation of the jaw, severe bruxism or clenching habits, and any mucosal disease except sporadic localized gingivitis were further exclusion criteria.

All patients who fulfilled the inclusion criteria were invited for re-examination by phone calls to visit the clinics and those who agreed to participate in the study signed a written informed consent based on Declaration of Helsinski, prior to the clinical evaluation. One researcher involved in the study, with high intra-examiner agreement and reproducibility carried out the clinical evaluation and radiographic MBL measurements. A small sample of nonparticipants was used for the evaluation of intra-examiner agreement and the measurements showed an agreement in $86 \%$ of the repeated measurements.

\section{Study Variables and Clinical Evaluation Protocol}

The following clinical variables were collected at baseline and retrospective evaluations after implant placement and prosthetic loading as possible predictors of MBL and implant failure as described previously $(3,17)$.

(a) Periodontal evaluation: (i) Peri-implant plaque index: presence or absence of plaque; (ii) Peri-implant sulcus bleeding index: presence or absence of sulcus bleeding; (iii) Peri-implant probing pocket depth: measured to the nearest millimeter with a Hu-Friedy PGF-GFS periodontal probe (Hu-Friedy, Chicago, IL, USA), calculated for each site. All measurements were performed at distal, vestibular, mesial, and palatal/lingual surfaces and the measurement of the deepest score was used as representative value $(18,19)$;

b) Implant-prosthetic evaluation: (i) Location: anterior and posterior regions; (ii) Prosthetic design: splinted or single crowns; (iii) Prosthetic retention: cemented or screwed crowns; (iv) Bone graft: presence or absence; (v) Implant design: diameter, length and type (2).

(c) Occlusion parameters evaluation: This analysis was dichotomically evaluated considering the following occlusal parameters: (i) Anterior guidance: adequate, when the mandible moves into a protrusive position and there are adequate implant and tooth-guided contacts on the anterior teeth to disocclude all posterior teeth immediately; or inadequate; (ii) Lateral guidance: group guidance, when the mandible moves forward into lateral position, and there are implant and tooth-guided contacts; or canine guidance, there are implant or tooth-guided contacts involving only tooth or implant); (iii) Occlusal platform: less wide, smaller area of occlusal contact; or normal, area of occlusal contact; (iv) Cusps: normal, cusps with normal height and width; or shallow, cusps lower and less wide than normal; (v) Nonworking contacts: absence or presence of tooth contact in nonworking side; (vi) Occlusal contacts: inadequate, premature intensity of occlusal contact, where a dark occlusal mark is an occlusal contact or premature contact (high spot); or adequate, a light occlusal mark is not necessarily an occlusal contact. The contacts between maxillary and mandibular teeth in static and dynamic movements were obtained by articulating Bausch Progress 100 micron paper (Bausch \& Lomb Incorporated, Kingston upon Thames, UK) and visually checked; (vii) Region of the implants: anterior or posterior (4).

For all parameters, the MBL was measured in standardized intra-oral periapical radiographs taken at preoperative or permanent crown installation (baseline) and at re-examination up to 9 years after permanent crown placement. All radiographs were taken using the long-cone paralleling technique and a plastic X-ray holder (Kodak Ektaspeed film, Eastman Kodak Co., Rochester, NY, USA) with a standardized exposure time of $0.8 \mathrm{~s}$. The images were digitized (SprintScan 35 Plus; Polaroid, Cambridge, MA USA) for measurements (Image Tool version 3.0, University of Texas Health Science Center, San Antonio, TX, USA). A computer-assisted calibration was performed for each radiograph by evaluation of the previous known values, such as fixture length, providing reliability and precision for the radiographic measurements. The following linear measurements between landmarks were taken: (1) The periimplant MBL was measured in millimeters $(\mathrm{mm})$ from the reference point, the shoulder of the implant, to the first visible bone level to implant contact at mesial and distal sides, (Fig. 1); (2) Each measurement was repeated three times and the mean was calculated; (3) The MBL around the implant over the years was calculated as the difference between the initial MBL and the MBL at the re-examination (initial MBL - final MBL) (18-20).

\section{Statistical Analysis}

The implants were the statistical unit considered in all analyses since patient-related predictors were controlled in this study. An implant was considered to have survived if it was clinically stable and complied with the function of supporting the prosthesis and caused no discomfort to the patient. Failure was defined as the removal of an implant for any reason. Data analysis included a descriptive analysis of the number of implants distribution for all study 
variables (Table 1). Relevant variables were entered into a multivariate marginal Cox proportional hazards regression model adjusted for clustering MBL observations, with significant correlation considered when $p<0.05$, (Tables 2 and 3 ).

The variables diameter and length were not analyzed with regression analysis due to variability of these data. Comparative statistics were performed (SPSS for Windows 19.0 Statistical Package, Chicago, IL, USA) and the history of the implants was investigated at the start from the dental records. Considering that the evaluated characteristics would affect outcomes of the trial more than the patients (better control of bias), the best possible statistical unit would be the implant, considered as the most informative experimental unit for this trial.

\section{Results}

Of the 89 patients who fulfilled the criteria for eligibility in the study, 4 could not be reached because of address and/or telephone number changes with respect to the data included in the database and 4 were not willing to participate in the investigation, because they lived too far from the clinic or they had work-related duties that $\vec{s}$ prevented them attending the appointment. A total of 82 patients (64\% women and 36\% men), with a mean age of $62 \pm 13$ were enrolled in this study and received external hexagon implants (Neodent, Curitiba, PR, Brazil) as described in Table 1. Included patients reported no diabetes or other relevant systemic diseases or any parafunctional habits. Only ten patients reported being current smokers (no more than 10 cigarettes per day), and two had been

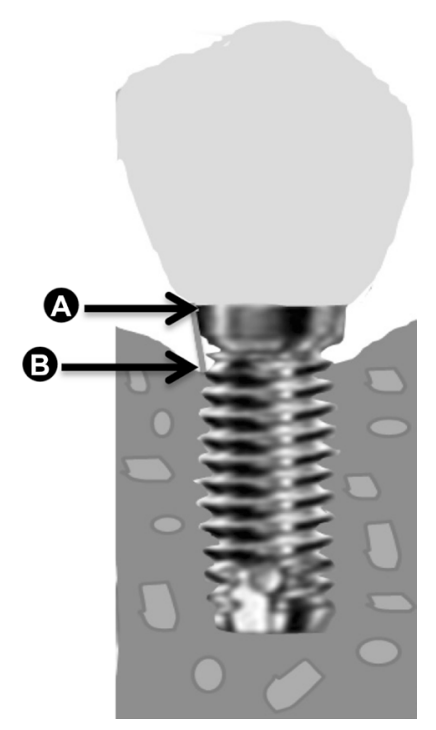

Figure 1. A: The periimplant MBL was measured in millimeters (mm) from the reference point, the shoulder of the implant. B: To the first visible bone level to implant contact at mesial and distal sides. diagnosed and treated for periodontal disease before the implant placement. Due to the low number of smokers and absence of any local or systemic diseases in the group, comparison between sub-groups of patients was not performed. A total of 164 external hexagon implants were clinically and radiographically examined (mean $3 \pm 1.5$ implants/patient), and the follow-up period after implant placement was $5.7 \pm 3.2$ years at two observation points in time (baseline and follow-up). The mean MBL was $1.4 \pm 0.6 \mathrm{~mm}$ (ranging from 0.56 to $3.2 \mathrm{~mm}$ ) and two implants displayed more than $3.4 \mathrm{~mm}$ of bone loss. From all the total 164 placed implants, only one patient lost 2 implants after two years of clinical function, showing an implant survival rate of $98.8 \%$. The failed implants were $10 \mathrm{~mm}$ long, $4.0 \mathrm{~mm}$ diameter and were supporting two splinted crowns with distal cantilever extension replacing molars. The implants were removed due to mobility and peri-implant infection. Despite these 2 failures, all evaluated prosthetic constructions were functioning. The most common prosthetic complication was abutment loosening, but veneer fracture and abutment loosening were not considered as failures in the study.

Table 1. Descriptive analyses of implant-supported restorations (82 patients, 164 implants)

\begin{tabular}{|c|c|}
\hline $\begin{array}{l}\text { Characteristics of implants } \\
\text { and prosthesis }\end{array}$ & $\begin{array}{l}\text { Number of implants } \\
\qquad(\mathrm{n}=164)\end{array}$ \\
\hline \multicolumn{2}{|l|}{ Implant type } \\
\hline External Hexagon & 164 \\
\hline \multicolumn{2}{|l|}{ Prosthetic retention } \\
\hline Cemented & 79 \\
\hline Screwed & 85 \\
\hline \multicolumn{2}{|l|}{ Implant diameters } \\
\hline 3.3 to 4.0 & 164 \\
\hline \multicolumn{2}{|l|}{ Lengths } \\
\hline 9 to $15 \mathrm{~mm}$ & 164 \\
\hline \multicolumn{2}{|l|}{ Implant location } \\
\hline Anterior & 77 \\
\hline Posterior & 87 \\
\hline \multicolumn{2}{|l|}{ Bone graft } \\
\hline With & 0 \\
\hline Without & 164 \\
\hline \multicolumn{2}{|l|}{ Prosthetic design } \\
\hline Single & 75 \\
\hline Splinted & 89 \\
\hline
\end{tabular}


Marginal Bone Loss

In Table 2, the Cox regression analysis showed no statistically significant difference in MBL at baseline and re-

Table 2. Multivariate Cox regression model (adjusted) for periodontal and implant-prosthetic risk factors associated with MBL (total 82 patients, 164 implants)

\begin{tabular}{|c|c|c|c|c|}
\hline $\begin{array}{l}\text { Periodontal and } \\
\text { implant-prosthetic } \\
\text { parameters }\end{array}$ & \multicolumn{2}{|c|}{$\begin{array}{l}\text { Hazard ratio } \\
\text { of MBL } \\
\text { (Mean) }\end{array}$} & $\begin{array}{c}95 \% \\
\text { Confidence } \\
\text { interval }\end{array}$ & $\begin{array}{c}\text { Robust } \\
\text { p-values }\end{array}$ \\
\hline $\begin{array}{l}\text { Periimplant sulcus } \\
\text { bleeding index }\end{array}$ & $\begin{array}{l}\text { Yes } \\
1.46\end{array}$ & $\begin{array}{l}\text { No } \\
1.39\end{array}$ & $(-0.89,0.47)$ & 0.891 \\
\hline $\begin{array}{l}\text { Periimplant } \\
\text { probing pocket } \\
\text { depth }\end{array}$ & $\begin{array}{c}\leq 3 \mathrm{~mm} \\
1.33\end{array}$ & $\begin{array}{c}\geq 3 \mathrm{~mm} \\
1.39\end{array}$ & $(-0.41,1.32)$ & 0.819 \\
\hline $\begin{array}{l}\text { Periimplant } \\
\text { plaque index }\end{array}$ & $\begin{array}{l}\text { Yes } \\
1.39\end{array}$ & $\begin{array}{l}\text { No } \\
1.24\end{array}$ & $(-1.16,-0.04)$ & $0.035^{* * *}$ \\
\hline $\begin{array}{l}\text { Implant } \\
\text { location }\end{array}$ & $\begin{array}{c}\text { Anterior } \\
1.34\end{array}$ & $\begin{array}{c}\text { Posterior } \\
1.39\end{array}$ & $(-0.65,0.51)$ & 0.809 \\
\hline $\begin{array}{l}\text { Prosthetic } \\
\text { retention }\end{array}$ & $\begin{array}{c}\text { Cemented } \\
1.55\end{array}$ & $\begin{array}{c}\text { Screwed } \\
1.30\end{array}$ & $(-0.13,-0.73)$ & $0.006^{* * *}$ \\
\hline Prosthetic design & $\begin{array}{c}\text { Single } \\
1.22\end{array}$ & $\begin{array}{c}\text { Splinted } \\
1.50\end{array}$ & $(0.03,0.62)$ & $0.030^{* *}$ \\
\hline
\end{tabular}

$\mathrm{MBL}=$ mean values of marginal bone loss, in millimeters; clustered marginal Cox regression analyses adjusted for clustered MBL observations for risk factors. **Indicates statistically significant differences between subgroups; $p<0.05$.

Table 3. Multivariate Cox Regression Model (adjusted) for occlusal risk factors associated with MBL (total 82 patients, 164 implants)

\begin{tabular}{|c|c|c|c|c|}
\hline $\begin{array}{l}\text { Occlusal } \\
\text { parameters }\end{array}$ & \multicolumn{2}{|c|}{$\begin{array}{l}\text { Hazard ratio of MBL } \\
\text { (Mean) }\end{array}$} & $\begin{array}{c}95 \% \\
\text { Confidence } \\
\text { interval }\end{array}$ & $\begin{array}{c}\text { Robust } \\
\text { p-values }\end{array}$ \\
\hline Cusp & $\begin{array}{c}\text { Shallow } \\
1.31\end{array}$ & $\begin{array}{c}\text { Normal } \\
1.36\end{array}$ & $(-0.38,0.31)$ & 0.845 \\
\hline $\begin{array}{l}\text { Occlusal } \\
\text { platform }\end{array}$ & $\begin{array}{c}\text { Normal } \\
1.32\end{array}$ & $\begin{array}{c}\text { Less wide } \\
1.37\end{array}$ & $(-0.41,0.77)$ & 0.550 \\
\hline $\begin{array}{l}\text { Occlusal } \\
\text { contact }\end{array}$ & $\begin{array}{c}\text { Adequate } \\
1.32\end{array}$ & $\begin{array}{c}\text { Inadequate } \\
1.38\end{array}$ & $(-0.11,0.5)$ & 0.203 \\
\hline $\begin{array}{l}\text { Lateral } \\
\text { guidance }\end{array}$ & $\begin{array}{c}\text { Canine } \\
1.22\end{array}$ & $\begin{array}{c}\text { Group } \\
1.61\end{array}$ & $(-0.53,-0.05)$ & $0.016^{* *}$ \\
\hline $\begin{array}{l}\text { Nonworking } \\
\text { contacts }\end{array}$ & $\begin{array}{c}\text { Absence } \\
1.25\end{array}$ & $\begin{array}{c}\text { Presence } \\
1.51\end{array}$ & $(0.006,0.77)$ & $0.046^{* * *}$ \\
\hline $\begin{array}{l}\text { Anterior } \\
\text { guidance }\end{array}$ & $\begin{array}{c}\text { Inadequate } \\
1.60\end{array}$ & $\begin{array}{c}\text { Adequate } \\
1.18\end{array}$ & $(-0.85,-0.25)$ & $0.001^{* * *}$ \\
\hline
\end{tabular}

$\mathrm{MBL}=$ mean values of marginal bone loss, in millimeters; Clustered marginal Cox regression analyses adjusted for clustered MBL observations for risk factors. **Indicates statistically significant differences between subgroups; $\mathrm{p}<0.05$. examination periods for the peri-implant sulcus bleeding index, peri-implant probing pocket depth and implant location. However, there was statistically significant difference when evaluating bone loss and prosthetic design $(p=0.030)$, prosthetic retention $(p=0.006)$ and periimplant plaque index $(p=0.035)$. The Cox regression analysis also showed statistically significant differences in MBL and occlusal parameters at baseline and re-examination periods for absence or presence of nonworking contacts $(p=0.047)$, lateral guidance versus group guidance $(p=0.015)$, and adequate versus inadequate anterior guidance $(p=0.001)$ (Table 3). The implant location did not show differences regarding implants placed in the anterior or posterior area $(p=0.809)$ (Table 3 ).

\section{Discussion}

In this study, Cox regression was carried out to identify which parameter (if any) could be associated to total or gradual bone loss around implants, and significantly higher MBL was found for inadequate occlusal scheme, peri-implant plaque and splinted and cemented crowns. Nonetheless, excellent longterm survival rate $(98.8 \%)$ was observed at $5.7 \pm 3.2$ years of follow-up; slightly above the reported survival rate of previous studies that used similar study design and follow-up $(2,20)$. Thus, the tested hypothesis was partially accepted, confirming that the long-term clinical success of dental implants is linked to multifactorial etiological factors (1-5). Only two implants failed two years after prosthetic loading probably because they were supporting splinted crowns with distal cantilever extension replacing molars. Radiography revealed large MBL at mesial implants, which indicated an overload situation. Overall, the mean MBL value was $1.4 \pm 0.6$ $\mathrm{mm}$, which corroborates the current literature and long-term studies that reported MBL to be approximately $1.5 \mathrm{~mm}$ during an approximate five-year period $(2,3)$. The variability of survival rate and MBL data reported in the current dental literature most likely occurs because there is still lack of homogeneity in complication reports for both implant and prosthetic parameters, which could lead to contradicted findings jeopardizing comparisons among studies. Yet, different methodologies, clinical scenarios, implant systems and time periods of examination and re-examination have been reported (2).

Concerning occlusal factors, the present findings showed that greater MBL was observed around the implants involved in inadequate occlusal schemes 
(absence of anterior guidance, presence of nonworking contacts and group function lateral guidance). These findings are in agreement with previous studies, which reported that inadequate occlusal pattern guides produced unfavorable forces on supportive structures and greater stress concentration at implant-bone contact (21). In fact, laterotrusive contacts, either in canine guidance or group function, have to provide adequate guidance to disocclude immediately all implants on the nonworking side $(20,21)$. Likewise, the protrusive position should also disocclude all posterior implants immediately $(4,21)$. In this study, lateral guidance involving teeth and implants provided greater bone loss around implants than lateral canine guidance involving only teeth or implants. This probably occurs because there are differences in the intensity of forces originated around the tooth and implant since implants do not display periodontium and periodontal mechanoreceptor feedback. Because of this, the fine motor control of mastication is reduced and does not restrict the load applied to implant-supported restorations, resulting in greater stress on crest bone and implant contact than in crest bone and tooth contact $(4,8,9)$. In contrast, this study showed that other occlusal factors, such as the height of $\dot{\vec{s}}$ the cusps, the width of the occlusal platform and occlusal contacts presented smaller MBL.

Regarding implant-prosthetic parameters, statistically significant differences were observed for cemented versus screwed, and single versus splinted crowns, with grater MBL observed for splinted and cemented prostheses. Although splinted implant-supported fixed partial denture may provide an approximately equal strain distribution of occlusal forces around implants during functional loading (22), single-tooth implants offer more comfortable prosthetic treatment because they provide better emergence profiles, improved passive fit of the metal framework and better oral hygiene access (23), corroborating the study findings. Besides, these results are in line with those from previous studies, which observed greater MBL for cemented compared to screw-retained implant-supported restorations $(14,22,24)$. These results may be ascribed to deficient removal of excess cement, leading to inflammation and resorption of marginal peri-implant bone (24). Another important consideration of cement restorations is the relative solubility of the cementation material. In most conditions, it may create retentive spaces for biofilm accumulation (14). Nonetheless, cemented restorations present more passive fit and better occlusal schemes (4), although clinical findings reported that this theoretical biomechanical advantage does not provide better crest bone stability over time (21). The implant location did not show differences regarding implants placed in the anterior or posterior area, while it should be observed that the implants placed in the anterior area had a shorter follow-up time ( 62 months, average $=51.2$ months) if compared with implants placed in the posterior area ( 115 months, average $=96$ months). This should be taken into consideration and may be considered a limitation of the present study; nonetheless, a 62-month (more than 5 years) period of follow-up is considered to be long, but unquestionably the period of observation in the posterior region provides a better indication of longevity.

For the peri-implant sulcus-bleeding index and periimplant probing pocket depth, no statistically significant difference on MBL at baseline and re-examination periods was found. These findings corroborate authors that refuted bacterial implications, and stated that although the infection in the soft tissue can be the most likely cause of bone loss around teeth, the MBL around implants may occur for other reasons in response to bone remodeling $(24,25)$. Additionally, the common periodontal indexes bleeding on probing and probing depth have no correlation with MBL around implants $(24,25)$. The present results may be explained by the fact that these two parameters do not necessarily represent chronic periodontal disease, resulting in no progressive bone loss over time. In fact, the absence of the association between sulcus bleeding and bone loss could only represent improper brushing at the moment of re-examination, and different peri-implant probing pocket depths could be related to the insertion position of the implant into the bone. Conversely, peri-implant plaque index showed positive correlation with MBL, thus preventive plaque removal has been shown to be effective in the maintenance of peri-implant health and implant stability $(6,7)$.

One of the strong points of this study were the exclusion criteria defined for enrollment patients since MBL around implants could be related to influence of patient-related factors such as local inflammatory response and smoking. Yet, the reproducibility of the method used to measure MBL and intra-examiner calibration, avoided variability in the measurements. There are new technologies used to calculate the difference between baseline and final re-examination including cone beam tomography. They offer greater accuracy in radiographic measurements and the possibility of tridimensional analysis. However, this intervention provides multiple exposures of the patients to radiation and Ethics Boards usually rule it out. In this study, MBL was measured by periapical radiographs, which have been described as ideal (25). Some limitations of this study concern its retrospective design. A potential bias of retrospective cross-sectional studies is the single follow-up observation that may not be enough to detect all factors associated to MBL over time and may not be enough to detect all factors associated to MBL over time; 
well-designed prospective randomized controlled clinical trials produce the best scientific evidence.

Further long-term clinical and radiographic research should be performed to understand the effects of the occlusal parameters on MBL because bone remodeling involves apposition and deposition and mechanical stress may have both positive and negative consequences depending on the magnitude, frequency and type of loading $(4,12-14)$. Within the limitations of this study, it was concluded that inadequate occlusal pattern guide, presence of visible plaque, and cemented and splinted implant-supported restorations were associated with greater MBL around the implant.

\section{Resumo}

Este estudo avaliou retrospectivamente a associação entre os parâmetros oclusais, periodontais e implante-protéticos e perda óssea marginal (POM) ao redor de implantes e taxa de sobrevivência, em 5,7 $\pm 3,2$ anos de acompanhamento após o carregamento protético. Oitenta e dois pacientes receberam um total de 164 implantes com hexágono externo. Após 0 periodo de cicatrização (3 à 6 meses), os implantes foram restaurados com coroa unitária ou até três coroas ferulizadas. Todos os pacientes seguiram um programa de manutenção rigoroso, com consultas regulares e avaliações clinicas realizadas por um examinador calibrado. As medições de POM obtidas de radiografias padronizadas realizadas na colocação da coroa permanente (baseline) e após a última avaliação foram calculadas considerando os parâmetros oclusais, periodontais e àqueles relacionados ao implante e prótese. Fratura na cerâmica de cobertura e afrouxamento do pilar não foram considerados fal has. Dois implantes falharam durante o periodo de acompanhamento, resultando em uma taxa de sobrevivência de 98,8\%.A análise de regressão de Cox mostrou POM associado com contatos no lado de balanceio $(p=0,047)$, inadequada guia anterior $(p=0,001)$, guia lateral em grupo envolvendo dentes e implantes $(p=0,015)$, indice de placa visivel em torno do implante $(p=0,035)$, tipo de prótese $(p=0,030)$ e retenção $(p=0,006)$. Guia de padrão oclusal inadequado, presença de placa visivel e restaurações implanto-suportadas cimentadas e ferulizadas resultaram em maior POM ao redor do implante.

\section{Acknowledgements}

The authors would like to thank the Sobracursos, Porto Alegre, Brazil, and the Prof. Luiz Augusto C. Paim, for allowing the use of the dataset

\section{References}

1. Galindo Moreno $P$, León-Cano A, Ortega-Oller I, Monje A, O Valle F, Catena A. Marginal bone loss as success criterion in implant dentistry: beyond $2 \mathrm{~mm}$. Clin Oral Implants Res. 2015;26:28-34.

2. Jung RE, Anja Z, Pjetursson BE, Marcel Z, Daniel ST. Systematic review of the survival rate and the incidence of biological, technical, and aesthetic complications of single crowns on implants reported in longitudinal studies with a mean follow-up of 5 years. Clin Oral Implants Res 2012;23:2-21.

3. Albrektsson $T$, Zarb G, Worthington P, Eriksson AR. The long-term efficacy of currently used dental implants: a review and proposed criteria of success. Int J Oral Maxillofac Implants 1986;1:11-25.

4. Klineberg IJ, Trulsson M, Murray GM. Occlusion on implants - is there a problem? J Oral Rehabil 2012;39:522-537.

5. Duyck J, VandammE K. The effect of loading on peri-implant bone: a critical review of the literature. J Oral Rehabil 2014;41;783-794.

6. Kozlovsky A, Tal H, Laufer BZ, Leshem R, Rohrer MD, Weinreb M, et al.. Impact of implant overloading on the peri-implant bone in inflamed and non-inflamed peri-implant mucosa. Clin Oral Implants Res
2007:18:601-610.

7. Miyata $T$, Kobayashi $Y$, Araki $H$, Ohto $T$, Shin K. The influence of controlled occlusal overload on peri-implant tissue. Part 4: a histologic study in monkeys. Int J Oral Maxillofac Implants 2002;17:384-390.

8. Ben-Gal G, Lipovetsky-Adler M, Haramaty O, Sharon E, Smidt A. Existing concepts and a search for evidence: a review on implant occlusion. Compend Contin Educ Dent 2013;34:26-31.

9. Kim Y, Oh TJ, Misch CE, Wang HL. Occlusal considerations in implant therapy: clinical guidelines with biomechanical rationale. Clin Oral Implants Res 2005;16:26-35.

10. Dinato TR, Grossi ML, Teixeira ER, Dinato JC, Sczepanik FS, Gehrke SA. Marginal bone loss in implants placed in the maxillary sinus grafted with anorganic bovine bone: a prospective clinical and radiographic study. J Periodontol 2016;4:1-13.

11. Sahrmann $P$, Naenni N, Jung RE, Held U, Truninger $T$, Hämmerle CHF, et al.. Success of $6-\mathrm{mm}$ implants with single-tooth restorations: A 3-year randomized controlled clinical trial. J Dent 2016. doi: 0022034516633432 [Epub ahead of print].

12. Derks J, Schaller D, Hakansson J, Wennstrom JL, Tomasi C, Berglundh T. Peri-implantitis - onset and pattern of progression. J Clin Periodontol 2016;43:383-388.

13. Yuan JC, Sukotjo C. Occlusion for implant-supported fixed dental prostheses in partially edentulous patients: a literature review and current concepts. J Periodontal Implant Sci 2013;43:51-57.

14. Yilmaz B, Seidt JD, McGlumphy EA, Clelland NL. Comparison of strains for splinted and non-splinted screw-retained prostheses on short implants. Int J Oral Maxillofac Implants 2011;26:1176-1182.

15. von Elm E, Altman DE, Egger M, Pocock SJ, Gøtzsche PC, Vandenbroucke JP. The Strengthening the Reporting of Observational Studies in Epidemiology (STROBE) Statement: Guidelines for Reporting Observational Studies. PLoS Medicine 2007;4:1623-1627.

16. Buser D, Weber HP, Lang NP. Tissue integration of non-submerged implants. 1- year results of a prospective study with 100 ITI hollowcylinder and hollow-screw implants. Clin Oral Implants Res 1990;1:3340.

17. Hultin M, Fischer J, Gustafsson A, Kallus $T$, Klinge B. Factors affecting late fixture loss and marginal bone loss around teeth and dental implants. Clin Oral Implants 2000;2:203-208.

18. Bazrafshan N, Darby I. Retrospective success and survival rates of dental implants placed with simultaneous bone augmentation in partially edentulous patients. Clin Oral Implants Res 2014;25:768-773.

19. Cosyn J, De Bruyn H, Cleymaet R. Soft tissue preservation and pink aesthetics around single immediate implant restorations: a 1-year prospective study. Clin Implant Dent Relat Res 2013;15:847-857.

20. Schneider D, Witt L, Hammerle CH. Influence of the crown-to-implant length ratio on the clinical performance of implants supporting single crown restorations: a cross-sectional retrospective 5-year investigation. Clin Oral Implants Res 2012;23;169-174.

21. Manns A, Miralles R, Valdivia J, Bull R. Influence of variation in antero posterior occlusal contacts on electromyographic activity. J Prosthet Dent 1989;61:617-623.

22. Sailer I, Mühlemann $S$, Zwahlen $M$, Hämmerle $C H F$, Schneider $D$. Cemented and screw-retained implant reconstructions: a systematic review of the survival and complication rates. Clin Oral Implants Res. 2012;23:163-201.

23. Blanes RJ, Bernard JP, Blanes ZM, Belser UC. A 10-year prospective study of ITI dental implants placed in the posterior region. II: Influence of the crown-to-implant ratio and different prosthetic treatment modalities on crestal bone loss. Clin Oral Implants Res 2007;18:707-714

24. De Brandão ML, Vettore MV, Vidigal Junior GM. Peri-implant bone loss in cement- and screw-retained prostheses: systematic review and meta-analysis. J Clin Periodontol 2013;40:287-295.

25. De Bruyn H, Vandeweghe S, Ruyffelaert C, Cosyn J, Sennerby L. Radiographic evaluation of modern oral implants with emphasis on crestal bone level and relevance to peri-implant health. Periodontol 2013;62:256-270. 